\title{
Determinan Leverage Optimal Di Bursa Efek Indonesia
}

\author{
Purwanto Widodo $^{\mathrm{a}, 1, *}$, Juardi ${ }^{\mathrm{b}, 2}$ \\ ${ }^{a}$ Institut Ilmu Sosial dan Manajemen STIAMI, Jakarta, Indonesia \\ b Institut Ilmu Sosial dan Manajemen STIAMI, Jakarta, Indonesia \\ ${ }^{1}$ purwantowidodo@gmail.com *; ${ }^{2}$ Juardi703@ gmail.com \\ * corresponding author
}

\section{ARTICLE INFO}

\section{Article History}

Received Oktober 2019

Revised Desember 2019

Accepted Januari 2020

\section{Keywords}

Capital Structure,

Static Model,

Dynamic Model

\begin{abstract}
Research on capital structure, recently characterized by the use of dynamic capital structure. The use of dynamic capital structure basically wants to know the existence of optimal leverage as hypothesized by Trade-Off Theory and Speed off Adjustment (SOA) to optimal leverage. This research tries to overcome this problem, by using dynamic panel data by using company characteristics and macroeconomic factors. The use of General Method of Moment (GMM) to overcome the problem of econometrics due to the use of dynamic models. Samples taken from manufacturing companies listing on the Indonesia Stock Exchange 2009-2015.

The inference model and the determinant behavior of capital structure can be explained by Trade-Off Theory and Pecking Order Theory. The variable characteristics of the company and macro economy are significant and are marked according to the hypothesis. The findings of this study include: the influence of profitability, size, tangibility, growth opportunity and business risk. In addition, on average companies in Indonesia can increase their debt to utilize tax shields
\end{abstract}

\section{PENDAHULUAN}

Tujuan perusahaan adalah memaksimalkan nilai perusahaan (value of the firm). Nilai perusahaan akan maksimal jika mampu meminimalkan biaya modal (Weighted Average Cost of Capital, WACC) dan biaya modal akan minimal ketika perusahaan memiliki leverage yang optimal (Ross et. al. (2008)). Jensen and Meckling, (1976)), berdasarkan agency theory menunjukkan bahwa leverage optimal dicapai dengan cara meminimalkan biaya keagenan yang terkait pendanaan ekuitas dengan biaya hutang, seperti biaya investasi (Myers, (1977)) dan aset substitusi (Jensen and Meckling, (1976)). Sedangkan menurut Ross (1977) model signaling theory, leverage akan optimal ditentukan oleh trade-off antara manfaat yang terkait dengan nilai pasar yang lebih tinggi dan signaling biaya dari perusahaan yang kredibel.

Lebih lanjut, Kraus dan Litzenberger (1973) menyatakan bahwa dengan adanya trade-off antara keuntungan pajak dari hutang dengan biaya kebangkrutan, maka leverage optimal akan tercapai ketika marjinal pajak pendapatan yang berasal dari pendanaan hutang sama dengan marjinal biaya kebangkrutan yang diharapkan. Teori ini menunjukkan bahwa pada saat leverage perusahaan belum tercapai titik optimum maka penggunaan hutang akan lebih murah jika dibandingkan dengan menerbitkan saham, tetapi setelah terlewati titik tersebut, maka hutang tidak menarik lagi karena perusahaan harus menanggung biaya keagenan, biaya kebangkrutan serta biaya bunga yang menyebabkan nilai saham turun. Hal inilah yang menyebabkan mengapa perusahaan akan selalu berusaha untuk menyesuaikan tingkat leverage aktual ke arah leverage optimal. Dengan demikian tingkat leverage aktual akan bergerak terus menerus dari waktu ke waktu sesuai dengan kondisi internal dan eksternal perusahaan menuju suatu target tertentu yang dinamakan dengan leverage yang optimal.

Berdasarkan hal tersebut, Heshmati (2001) menyatakan bahwa model statis tidak sesuai lagi untuk menduga leverage optimal, karena pada waktu tertentu akan terjadi deviasi antara leverage actual dengan leverage optimal, karena itu, disarankan untuk menggunakan model dinamis. Gaud et al. (2005) menunjukkan bahwa pergerakan leverage actual dari waktu ke waktu tersebut, merupakan ciri dinamis.

Dalam perspektif dinamis, leverage optimal tersebut tidak bisa diamati secara langsung (unobservable), yang bisa diamati adalah arah dan kecepatan dari proses penyesuaian tersebut (Darminto dan Manurung (2008)). Dengan demikian, leverage optimal tersebut perlu dispesifikasi terlebih dahulu 
dengan menggunakan factor-faktor determinan, yaitu karakteristik perusahaan (Heshmati (2001), Ozkan (2001) dan Gaud et al. (2005), Algahtani dan Alnori (2019)) dan factor ekonomi makro (Drobetz dan Wanzenried (2004), Haas dan Peeters (2004), Haron dan Ibrahim (2012), Haron et al. (2013), Haron et al. (2013), Yang, Albaity dan Hassan (2015), Yang, Albaity dan Hassan (2015), Kinyua dan Muria (2017), Syihab (2018)).

Penelitian ini bermaksud untuk menganalisis perilaku determinan leverage yang ditargetkan perusahaan-perusahaan yang listing di Bursa Efek Indonesia, khususnya sector sekunder. Hasil analisis menunjukkan bahwa variable karakteristik perusahaan : profitability, size, tangibility, growth opportunity, business risk dan kondisi ekonomi makro seperti pertumbuhan ekonomi, inflasi dan suku bunga merupakan variabel penting dalam menduga leverage optimal. Temuan menarik penelitian ini adalah pengelolaan profitabilitas, perusahaan di Indonesia dalam jangka pendek akan mengikuti Pecking Order Theory dan jangka panjang Trade Of Theory, terdapatnya pengaruh Size (Size Effect), dimana perusahaan yang memiliki size kecil, memiliki pengaruh lebih besar. Kecepatan penyesuaian berkisar antara $30.12 \%$ sampai $38.01 \%$, sesuai dengan Dynamic Trade Off Theory.

Selain itu, diharapkan penelitian ini akan memberikan tambahan wawasan mengenai model dinamis, khususnya data panel dinamis, dengan demikian diharapkan akan mampu mengatasi kesenjangan dalam literature penelitian struktur modal di Indonesia dengan cara memadukan pendekatan teori dan ekonometrik yang kuat sehingga akan memberikan hasil yang komprehensif.

\section{METODE}

Metodologi penelitian dengan pendekatan dinamis berbeda dengan pendekatan statis. Penelitian model dinamis, dilakukan untuk mengatasi kekurangan dari model statis dimana ketidakmampuan model statis untuk menangkap penyesuaian dinamis dari leverage aktual ke leverage optimal.

Penelitian model dinamis pada struktur modal ditandai dengan adanya 2 (dua) parameter yang diduga, yaitu : Leverage optimal dan Kecepatan Penyesuaian (SOA, speed of adjustment). Dua parameter tersebut, dapat dianalisis dalam satu model (Ozkan (2001), Gaud et. al, (2005), Haron and Ibrahim (2012)) atau dalam model yang terpisah (Hesmati, (2001), Mahakud and Mukhrejee (2011), Nivorozhkin (2003), Lööf (2003), Nosita (2016) dan Effendi et al. (2016)).

Pada awalnya, perusahaan akan menetapkan leverage optimal untuk periode yang akan datang (Flannery dan Rangan (2006)). namun akibat dari pergerakan determinannya sebagai respon dari perkembangan kondisi internal dan eksternal perusahaan sehingga leverage saat kini akan berubah, akibatnya akan terjadi deviasi antara leverage actual dengan leverage optimal. Untuk menuju leverage optimal tersebut, dibutuhkan waktu dan biaya (adjustment cost) (Fisher et al. (1989), Frank dan Goyal (2005), Flannary dan Hankins (2007).

Hal inilah yang membuat kenapa kecepatan penyesuaian antara satu perusahaan dengan lain tidak sama juga antar sector industry dan antar negara. Clark, Francis and Hasan (2009), Flannery and Rangan (2006), Lemmon, Robert dan Zender (2008), De Haas dan Peeters (2006) dan Drobetz dan Wanzenried (2006)) menunjukkan adanya pengaruh factor ekonomi makro, Cook dan Tang (2006) menunjukkan bahwa pada kondisi pertumbuhan ekonomi yang baik maka pergerakan leverage menuju leverage optimal lebih cepat dibandingkan jika pertumbuhan ekonomi memburuk.. Penelitian Getzman, Lang dan Spremann $(2010,2015)$ menunjukkan adanya perbedaan diantara sector industry diantara negara di Asia, Eropa dan US, penelitian di Indonesia yang dilakukan oleh Saadah dan Priyadi (2012) juga menunjukkan perbedaan sub sector industry. Lööf (2003) terdapat perbedaan determinan leverage optimal akibat system keuangan berbeda yang diterapkan oleh negara.

Secara Ekonometrik, model untuk pendugaan leverage optimal menggunakan PAM (Partial Adjustment Model) sebagai berikut :

$$
\begin{aligned}
& L E V_{i t}^{*}=F\left(Y_{i t}, X_{i}, X_{t}\right) \\
& \text { (Hesmati, 2001) } \\
& L E V_{i t}^{*}=\text { Leverage optimal merupakan fungsi dari : } \\
& Y_{i t}=\text { faktor-faktor yang mempengaruhi leverage yang optimal, } \\
& X_{i}=\text { firm spesific } \\
& X_{t}=\text { time spesific (time dummy (or time trend) variables) }
\end{aligned}
$$


Dimana $L E V_{i t}^{*}$ yang merupakan fitted dari persamaan 1 yang dianggap sebagai leverage optimal dari perusahaan ke-i pada waktu yang ke-t, dipengaruhi oleh $Y_{i t}$ variabel yang mencerminkan karakteristik perusahaan. Pada kondisi ideal sebagaimana diasumsikan oleh teori Modigliani dan Miller $(1958,1963)$ yaitu kondisi pasar modal yang sempurna, pada kondisi ekuilibrium atau pada jangka panjang maka leverage aktual $\left(L E V_{i, t}\right)$ pada waktu ke-t seharusnya sama dengan leverage optimal $\left(L E V_{i t}^{*}\right)$, menurut (Lóóf, 2003):

$$
L E V_{i, t}=L E V_{i, t}^{*}
$$

Jika keduanya dikurangkan dengan leverage waktu sebelumnya, maka persamaan 2 menjadi :

$$
L E V_{i, t}-L E V_{i, t-1}=L E V_{i, t}^{*}-L E V_{i, t-1}
$$

Persamaan 3 dapat dibaca : dalam kondisi ideal, maka perubahan menuju leverage aktual pada waktu ke-t akan sama dengan perubahan menuju ke leverage yang optimal. Namun kenyataannya tidak sesederhana itu, untuk menuju ke leverage optimal tersebut dibutuhkan waktu dan biaya, Myers (1984) dan Fischer et. al. (1989) menunjukkan bahwa biaya tersebut sebagai biaya penyesuaian (adjustment cost), dimana besarnya biaya penyesuaian tersebut tergantung dari kondisi internal perusahaan itu sendiri. Lebih lanjut Fischer et. al. (1989) menunjukkan bahwa perusahaan tidak akan melakukan penyesuaian secara penuh menuju ke leverage yang ditargetkan namun dilakukan sebagian demi sebagian, sehingga persamaan 3 tersebut menjadi :

$$
L E V_{i, t}-L E V_{i, t-1}=\delta_{i, t}\left(L E V_{i, t}^{*}-L E V_{i, t-1}\right)
$$

Persamaan 4 merupakan model PAM (Partial Adjustment Model) yang merupakan pengembangan lebih lanjut dari ARDL (Autoregressive distribution lag model), atau juga disebut Stock Adjustment Model, suatu model yang dikembangkan oleh Mark Nerlove tahun 1958 berdasarkan model Koyck (Widarjono, (2009)). Sedangkan parameter $\delta_{i, t}$ merupakan kecepatan penyesuaian (Speed of Adjustment, SOA) yang dilakukan oleh perusahaan untuk menuju leverage optimal, dalam bahasanya Greene (2003) desired level of $y_{t}$.

Parameter $\delta_{i, t}$ menunjukkan besarnya magnitude penyesuaian antara dua periode waktu yang berurutan atau dengan kata lain didesain untuk menangkap kecepatan perubahan ke leverage optimal $\left(L_{i, t}^{*}\right)$ dari tahun sebelumnya $\left(L E V_{i, t-1}\right)$. Jika nilai $\delta_{i, t}=1$, menunjukkan bahwa penyesuaian menuju leverage optimal berlangsung seketika, yaitu dalam satu periode, sehingga leverage aktual $\left(L E V_{i, t}\right)$ tepat sama dengan leverage optimal $\left(L E V_{i, t}^{*}\right)$ pada akhir periode. Jika $\delta_{i, t}<1$ menunjukkan bahwa perusahaan belum melakukan penyesuaian secara optimal, sehingga tidak berada pada struktur modal yang optimal. Sementara itu, untuk $\delta_{i, t}=0$, maka perusahaan tidak melakukan penyesuaian. Semakin mendekati 1, menunjukkan bahwa semakin tinggi kecepatan penyesuaian dari perusahaan tersebut, artinya semakin mendekati leverage optimal sehingga nilai perusahaan semakin tinggi, sebaliknya jika mendekati 0 .

Lebih lanjut persamaan 4 , dapat disederhanakan menjadi :

$$
L E V_{t}=(1-\delta) L E V_{t-1}+\delta L E V_{t}^{*}
$$

Penyesuaian ke arah leverage optimal merupakan konsep struktur modal dinamis sesuai dengan apa yang diharapkan oleh Dynamic Trade-Off Theory. Teori ini berasumsi bahwa penyimpangan dari leverage optimal tersebut adalah kondisi yang membutuhkan biaya yang tidak sedikit sehingga menuntut manajer agar segera mengambil tindakan cepat untuk kembali ke leverage optimal.

Secara ringkas (Myers, 1984) menyatakan bahwa Dynamic Trade-Off Theory ditandai pertama-tama perusahaan akan menetapkan target leverage optimal kemudian secara gradual (to drift) akan menyesuaikan struktur modal mereka menuju leverage optimal. Perusahaan yang berada dalam kondisi terdeviasi antara leverage actual dengan leverage optimal memiliki dua pilihan yaitu bergerak menuju ke leverage optimal atau bertahan pada posisi yang menyimpang. Perusahaan akan memutuskan untuk menuju ke leverage optimal jika menganggap bahwa biaya penyesuaian lebih kecil daripada biaya deviasi dari leverage optimal.

Lebih lanjut, Xu (2007) menyatakan besarnya kecepatan penyesuaian, dapat dijadikan acuan untuk menentukan kebijakan struktur modal yang dianut oleh perusahaan itu. Semakin tinggi kecepatan penyesuaian, berarti perusahaan tersebut memiliki biaya penyesuaian yang rendah sehingga memiliki kesempatan lebih besar untuk meningkatkan hutang, hal ini sesuai dengan Trade-Off Theory, sebaliknya

Purwanto Widodo, et.al (Determinan Leverage Optimal Di Bursa Efek Indonesia...) 
jika kecepatan penyesuaian rendah berarti perusahaan tersebut tidak memiliki target leverage optimal, hal tersebut sesuai dengan Pecking Order Theory. Penelitian Flannery dan Rangan (2006) dengan kecepatan penyesuaian sebesar 34.1\% konsisten dengan Dynamic Trade-Off Theory, sedangkan Huang dan Ritter (2005) dengan kecepatan penyesuaian 11.3\% dianggap sesuai dengan Market Timing Theory.

Dengan diketahui nilai kecepatan penyesuaian, maka akan dapat dihitung waktu setengah (HalfLives) yaitu waktu dibutuhkan bagi perubahan leverage menuju perubahan yang permanen leverage yang ditargetkan. Iliev dan Welch (2010) menyatakan bahwa waktu setengah (half-lives) adalah waktu yang dibutuhkan oleh perusahaan untuk menuju kembali setengah (one-half) dari jarak antara leverage yang terobeservasi dengan leverage yang ditargetkan setelah terjadi 1 unit goncangan (shock) yang terjadi pada error term $\left(\varepsilon_{i t}\right)$. Untuk proses $\mathrm{AR}(1)$, waktu setengah (half-lives) dihitung dengan rumus $: \frac{\log (0.5)}{\log \left(1-\delta_{i, t}\right)}$. Sedangkan Widarjono (2013) menyatakan half-lives merupakan kelambanan median, yaitu waktu setengah yang dibutuhkan bagi perubahan variabel dependen karena perubahan dari variabel independent. Misalkan kelembanan median sama dengan 0,4306 artinya perubahan setelah varaiabel dependent hanya memerlukan waktu kurang dari setengah periode. Sedangkan waktu yang dibutuhkan oleh perusahaan untuk menuju leverage yang ditargetkan yaitu $\frac{1}{\delta_{i, t}}$ tahun.

Penelitian Flannery dan Rangan (2006) menunjukkan bahwa kecepatan penyesuaian perusahaan di Amerika Serikat tahun 1965 - 2001, berkisar antara 34\% sampai 35.5\% atau $1.6-1.7$ tahun waktu yang dibutuhkan untuk mencapai setengah dari target leverage ketika terjadi shock dan untuk menuju leverage yang ditargetkan dibutuhkan waktu 2.82 samapai 2.94 tahun.

\section{Determinan Leverage Optimal}

Sebagaimana penelitian Lemmon, Robert dan Zender (2008), De Haas dan Peeters (2006) dan Drobetz dan Wanzenried (2006) yaitu adanya pengaruh factor karakteristik perusahaan dan ekonomi makro terhadap leverage optimal. Beberapa factor tersebut adalah :

\section{Profitability (PROF)}

Menurut Pecking Order Theory, ketika tingkat profitability tinggi yang menunjukkan bahwa ketersediaan dana cash yang besar, sehingga untuk menghindari asymmetric information sebaiknya digunakan dana internal (Myers dan Majluf (1984)), Oleh karena itu, penelitian ini memprediksi hubungan negatif dengan leverage (Haron et. al. (2013); Ying, Albaity and Zainir (2016). Penelitian ini menggunakan proxy Haas and Peeters (2004) dan Nosita (2016) yaitu EBIT to Total Asset.

\section{Size (SIZE)}

Titman dan Wessel (1988), menyatakan bahwa size merupakan variabel yang dapat dijadikan sebagai proksi default, karena perusahaan besar cenderung lebih terdiversifikasi produknya sehingga arus kas relatif stabil, akibatnya probablilitas defaultnya juga rendah. Karena itu, penelitian ini memprediksi bahwa size akan berhubungan positif dengan leverage. Penelitian ini menggunakan proxy Gaud et. al. (2005) yaitu menggunakan logaritma penjualan bersih.

\section{Growth Opportunity (GROWTH)}

Perusahaan yang memiliki growth opportunity tinggi memiliki keterbatasan dalam kemampuan mengakses hutang karena masalah kebangkrutan (Gaud et. al. (2005)). Karena itu, diprediksi growth opportunity berhubungan negatif dengan leverage. Penelitian ini, mengunakan proxy Mazur (2007) yaitu perubahan sales.

\section{Tangibility (TANG)}

Semakin tinggi proporsi aset tangible yang dimiliki perusahaan, menunjukkan bahwa semakin tinggi aset yang dapat dijadikan jaminan ketika perusahaan mengakses fihak eketernal, sehingga mengurangi biaya keagenan akibat hutang (Nivorozhkin, 2003). Karena itu, penelitian ini memprediksi bahwa tangibility berhubungan positif dengan leverage. Penelitian ini mengacu pada Banerjee, Hesmati and Wihlborg (2000), yaitu Fixed Asset to Total Asset. 


\section{Business Risk (RISK)}

Business Risk menunjukkan variabilitas pendapatan, semakin tinggi variabilitas pendapatan, semakin tinggi kemungkinan kebangkrutan yang timbul, sehingga diprediksi business risk berhubungan negative dengan leverage. (Heshmati, (2001); Lóóf, (2003); Nivorozhkin, (2003); Banerjee et al. (2000)). Penelitian ini mengacu Haron et. al. (2013) yaitu perubahan EBIT.

\section{Pertumbuhan Ekonomi (GPDB)}

Bank Indonesia menunjukkan bahwa ketika perekonomian membaik, banyak perusahaan melakukan IPO ((Initial Public Offering), right issue atau penerbitan obligasi, sebaliknya ketika terjadi kontraksi ekonomi, yang berakibat terjadi penurunan keuntungan yang diperoleh perusahaan, maka banyak perusahaan menggunakan dana internal untuk membiayai investasi perusahaan (Laporan Perekonomian Indonesia). Hackbarth, Miao dan Morellec (2006) perkembangan kondisi ekonomi makro suatu negara berpengaruh terhadap pergerakan leverage actual terhadap leverage yang ditargetkan. Mat Nor et al. (2011) dan Haron dan Ibrahim (2013) menggunakan proxy perubahan GDP tahunan, hasilnya menunjukkan hasil yang positif antara pertumbuhan ekonomi dengan leverage.

\section{Inflasi (INFLASI)}

Peningkatan inflasi akan menyebabkan meningkatnya taxes shield (keuntungan pajak) karena meningkatkan jumlah hutang (Targart, (1986)), sehingga diharapkan inflasi akan berhubungan positif dengan leverage. Inflasi diproxykan dengan perubahan Indeks Harga Konsumen (IHK) tahunan (Yin, Albaity dan Zainir (2016)).

\section{Suku Bunga (BUNGA)}

Peningkatan suku bunga akan meningkatkan biaya yang ditanggung oleh perusahaan, sehingga akan mengurangi keinginan perusahaan berhutang dengan demikian peluang terjadinya financial distress akan menurun (Deesomsak et al. 2004). Dincergok dan Yalciner (2011) yang menyatakan bahwa suku bunga berpengaruh negatif terhadap struktur modal perusahaan. Suku bunga berdasarkan suku bunga bank tahunan yang diterbitkan oleh Bank Indonesia.

\section{Variabel Dependen}

Variabel dependen dalam dalam penelitian ini adalah leverage (LEV) berasal dari nilai buku, yang diproxykan dengan total hutang dibagi dengan total aset. Menurut Rajan dan Zingales (1995), total hutang akan mencerminkan rasio leverage yang sesungguhnya, karena penggunaan total hutang mencerminkan penggunaan baik untuk pembiayaan (financing) maupun transaksi usaha.

\section{Data dan Metodologi}

Penelitian ini menggunakan perusahaan sekunder yang listing di Bursa Efek Indonesia terkait dengan struktur modal, waktu penelitian tahun 2009 sampai dengan 2015, namun data yang diperlukan adalah data laporan keuangan perusahaan tahun 2008 sampai dengan 2015. Perusahaan yang termasuk kedalam sector sekunder adalah : industri dasar dan kimia/basic industry and chemical; aneka industri/miscellaneous industry dan industri barang konsumsi/consumer goods industry. Perusahaan tersebut telah terdaftar sebelum tahun 2018 dan selama pengamatan tidak mengalami delisting.

Dengan menggabungkan persamaan 1 dan 5, maka akan diperoleh :

$$
L E V_{t}=(1-\delta) L E V_{t-1}+\delta F\left(Y_{i t}, X_{i}, X_{t}\right)
$$

Persamaan 6, dapat ditulis kembali dalam model ekonometrika, menjadi :

$$
L E V_{t}=(1-\delta) L E V_{t-1}+\delta\left(\beta \mathrm{x}_{\mathrm{i}, \mathrm{t}}^{\prime}+\mu_{\mathrm{i}, \mathrm{t}}\right) \text {. }
$$

Dengan mengsubtitusi $\gamma_{0}=(1-\delta) ; \gamma_{k}=\delta \beta$ dan $e_{i, t}=\delta \mu_{\mathrm{i}, \mathrm{t}}$ sehingga persamaan 7 menjadi :

$$
L E V_{t}=\gamma_{0} L E V_{t-1}+\gamma_{k} \mathrm{x}_{\mathrm{i}, \mathrm{t}}^{\prime}+\mathrm{e}_{\mathrm{i}, \mathrm{t}}
$$

Dimana $\mathrm{x}_{\mathrm{i}, \mathrm{t}}^{\prime}$ merupakan matrik dari variable bebas yang terdiri atas karakteristik perusahaan dan ekonomi makro. Sedangkan bentuk persamaan 8 merupakan data panel dinamis, karena $L E V_{t}$ merupakan fungsi dari $\mathrm{e}_{\mathrm{i}, \mathrm{t}}$ maka $L E V_{t-1}$ juga merupakan fungsi dari $\mathrm{e}_{\mathrm{i}, \mathrm{t}}$, suatu hal yang tidak diijinkan dalam pendekatan berbasis 
OLS (Ordinary Least Square), karena adanya masalah endogenitas. Akibatnya model Fixed Effect (FE) maupun Random Effect (RE) menghasilkan penduga bias dan tidak konsisten ((Verbeek, 2004).

Verbeek (2004) memberi contoh dalam bentuk data panel autoregresif tanpa menyertakan variable eksogen, yaitu :

$$
y_{i t}=\gamma y_{i, t-1}+\mu_{i t} ;|\gamma|<1 ; t=1,2, \ldots \ldots \ldots . T
$$

dengan $\mu_{i t}=u_{i}+v_{i t}$ dimana $u_{i} \sim \operatorname{IID}\left(0, \sigma_{u}^{2}\right)$ dan $v_{i t} \sim \operatorname{IID}\left(0, \sigma_{v}^{2}\right)$ saling bebas satu sama lain. Penduga model FE adalah $\gamma$, sehingga pendugaan untuk $\hat{\gamma}_{F E}$ yaitu :

$\hat{\gamma}_{F E}=\frac{\sum_{i=1}^{N} \sum_{t=1}^{T}\left(y_{i t}-\bar{y}_{l}\right)\left(y_{i t-1}-\bar{y}_{i-1}\right)}{\sum_{i=1}^{N} \sum_{t=1}^{T}\left(y_{i t}-\bar{y}_{l}\right)^{2}}$

Dengan :

$\bar{y}_{t}=\frac{\sum_{t=1}^{T} y_{i t}}{T}$

$\bar{y}_{i-1}=\frac{\sum_{t=1}^{T} y_{i, t-1}}{T}$

Untuk menganalisis sifat penduga $\hat{\beta}_{F E}$, dapat dilakukan dengan cara mensubsitusikan persamaan 9 ke persamaan 10 (Verbeek, 2004 p: 393 -397), maka:

$\hat{\gamma}_{F E}=\gamma+\frac{\left(\frac{1}{N T}\right)\left(\sum_{i=1}^{N} \sum_{t=1}^{T}\left(v_{i t}-\bar{v}_{l}\right)\left(y_{i t-1}-\bar{y}_{i-1}\right)\right.}{\sum_{i=1}^{N} \sum_{t=1}^{T}\left(y_{i t-1}-\bar{y}_{i-1}\right)^{2}}$

Penduga ini bersifat bias dan tidak konsisten untuk $N \sim \infty$ dan T tetap, karena bentuk pembagian dari persamaan tersebut tidak memiliki nilai harapan yang sama dengan nol dan tidak konvergen menuju nol bila $N \sim \infty$. Untuk mengatasi hal itu, Arrelano dan Bond (1991) menyarankan menggunakan pendekatan Generalized method of moments (GMM). Lebih lanjut, Verbeek (2004) menunjukkan bahwa pendekatan first-difference dapat mengandung bias pada sampel terbatas (berukuran kecil), hal tersebut karena tingkat lag (lagged level) dari deret berkorelasi secara lemah dengan first-difference berikutnya, sehingga instrument variable yang tersedia untuk persamaan first-difference menjadi lemah dan tidak efisien (Blundell dan Bond, (1998)), karena itu disarankan untuk menggunakan metode system GMM. Berbeda dengan model first-difference GMM, model system GMM menggunakan lagged level dari $\mathrm{y}_{\mathrm{i}, \mathrm{t}}$ sebagai variable instrument baik pada first difference dan level, sehingga tidak hanya menggunakan momen kondisi dan matriks variable instrument dari model first difference tetapi juga dan variable instrument level.

Agar pendekatan GMM valid, maka menurut Arellano dan Bond (1991), harus memenuhi:

1. Uji Wald

Uji Wald merupakan uji signifikansi model secara simultan untuk mengetahui ada tidaknya hubungan di dalam model. Hipotesis Uji Wald menurut Arellano dan Bond (1991) adalah: $\mathrm{H}_{0}$ : Tidak terdapat hubungan di dalam model. dengan statistic ujinya:

$$
w=\hat{\beta}^{\prime} \hat{V}^{-1} \hat{\beta} \sim \chi_{(K)}^{2}
$$

Dimana $\widehat{V}=\sum_{i=1}^{N} Z_{i}^{\prime} \Delta v_{i} \Delta v_{i}^{\prime} Z_{i}$, dengan k banyaknya parameter yang diduga. Keputusan tolak $\mathrm{H}_{\mathrm{o}}$ jika nilai statistic uji w lebih besar dari taraf nyata. Dalam penelitian ini, diharapkan tolak $\mathrm{H}_{\mathrm{o}}$

2. Uji Sargan

Uji Sargan digunakan untuk mengetahui validitas penggunaan variable instrumen yang jumlahnya melebihi jumlah parameter yang diduga (kondisi overidentifying restriction). Hipotesisnya adalah $\mathrm{H}_{0}$ : Kondisi overidentifying restriction dalam pendugaan model valid dengan statistic ujinya:

$s=\hat{v}^{\prime} Z\left[\sum_{i=1}^{N} Z_{i}^{\prime} \hat{v}_{i} \hat{v}_{i}^{\prime} Z_{i}\right]^{-1} Z^{\prime} \hat{v} \sim \chi_{(p-k-1)}^{2}$ 
Dengan $\hat{v}$ merupakan error term bagi penduga model. Keputusan tolak $\mathrm{H}_{\mathrm{o}}$ jika nilai statistic uji s lebih besar dari $\chi_{(p-k-1)}^{2}$ dengan p merupakan jumlah kolom bagi Z. Dalam penelitian ini, diharapkan akan terima $\mathrm{H}_{0}$.

3. Uji Arrellano - Bond

Statistik ujinya adalah:

$m_{i}=\frac{\hat{v}_{-i}^{\prime} \hat{v}_{*}}{\hat{v}^{1 / 2}} \quad \tilde{a} N(0,1)$

$E\left(v_{i t} v_{i(t-2)}\right)=0$ dengan

$\hat{v}=\sum_{i=1}^{N} v_{i(-2)}^{\prime} \hat{v} * v_{i}^{\prime} \hat{v}_{i(-2)}-2 \hat{v}_{-2}^{\prime} X_{*}\left(X^{\prime} Z A_{N} Z^{\prime} X\right)^{-1} X^{\prime} Z A_{N}\left(\sum_{i=1}^{N} Z_{i}^{\prime} \hat{v} * v_{i}^{\prime} \hat{v}_{i(-2)}\right)+$

$\hat{v}_{-2}^{\prime} X_{*} \operatorname{avâr}(\hat{\delta}) X_{*}^{\prime} \hat{v}_{-2} \operatorname{dimana} T_{i} \geq 5$

Dengan $\mathrm{i}=1,2 ; \mathrm{m}_{\mathrm{i}}$ merupakan statistic Arellano - Bond ke-i, $\hat{v}_{-i}^{\prime}$ merupakan vector error lag ke-i dari pendugaan persamaan regresi, sedangkan $\hat{v}_{*}$ merupakan q x 1 vektor yang dipotong untuk menyesuaikan $\hat{v}_{-i}^{\prime}$ dimana $\mathrm{q}=\mathrm{N}(\mathrm{T}-2-\mathrm{i})$ dan $\hat{v}$ pada persamaan 9 merupakan vector penduga error dari Arrellano Bond (1991). Statistik uji Arellano- Bond mengikuti distribusi normal, keputusan tolak $\mathrm{H}_{\mathrm{o}}$ apabila $\mathrm{m}_{\mathrm{i}}$ lebih besar dari $\mathrm{Z}_{\alpha}$. Model dikatakan konsisten apabila terdapat autokorelasi pada error first difference orde ke-1 (dengan kata lain Tolak $\mathrm{H}_{\mathrm{o}}$ untuk $\mathrm{m}_{1}$ ) dan tidak terdapat autokorelasi pada error first difference pada error first difference orde orde ke-2 (terima $\mathrm{H}_{\mathrm{o}}$ untuk $\mathrm{m}_{2}$ ).

4. Tidak bias

Estimator GMM dikatakan tidak bias, jika nilai koefisien dari lag variable dependent (dalam hal ini lag Leverage) yang diperoleh dari proses GMM terletak diantara lag leverage FE dan lag leverage PLS/OLS ( Zu (2007)).

\section{HASIL DAN PEMBAHASAN}

Hasil analisis dapat dilihat pada Tabel dibawah ini:

Tabel

Determinan Leverage Optimal

\begin{tabular}{|c|c|c|c|c|c|c|c|c|c|}
\hline Variabel & 1 & 2 & 3 & 4 & 5 & 6 & 7 & 8 & 9 \\
\hline \multirow{4}{*}{ Lag LEV } & 0.6587 & 0.6542 & 0.6894 & 0.6306 & 0.6217 & 0.63332 & 0.6217 & 0.58633 & 0.6128 \\
\hline & 3 & 9 & 3 & 9 & 4 & 0 & 4 & 3 & 7 \\
\hline & $(0.01)^{*}$ & $(0.01)^{*}$ & $(0.01)^{*}$ & $(0.01)^{*}$ & $(0.01)^{*}$ & $(0.01)^{* *}$ & $(0.01)^{*}$ & $(0.01)^{* *}$ & $(0.01)^{*}$ \\
\hline & $* *$ & $* *$ & $* *$ & $* *$ & $* *$ & $*$ & $* *$ & $*$ & $* *$ \\
\hline \multirow{4}{*}{ PROF } & -0.3860 & -0.3842 & -0.2999 & 0.3910 & -0.4934 & -0.38164 & -0.4934 & -0.31457 & -0.4071 \\
\hline & & & & 4 & & & & & \\
\hline & $(0.02)^{*}$ & $(0.04)^{*}$ & $(0.04)^{*}$ & $(0.04)^{*}$ & $(0.03)^{*}$ & $(0.03)^{* *}$ & $(0.03)^{*}$ & $(0.01)^{* *}$ & $(0.03)^{*}$ \\
\hline & $* *$ & $* *$ & $* *$ & ** & $* *$ & * & $* *$ & * & ** \\
\hline \multirow[t]{3}{*}{$\begin{array}{l}\text { Lag } \\
\text { PROF }\end{array}$} & & -0.2042 & & & & & & & \\
\hline & & $(0.03)^{*}$ & & & & & & & \\
\hline & & $* *$ & & & & & & & \\
\hline \multirow[t]{3}{*}{ DPROF } & & & -0.1818 & & & & & & \\
\hline & & & $(0.04)^{*}$ & & & & & & \\
\hline & & & $* *$ & & & & & & \\
\hline \multirow{4}{*}{ SIZE } & 0.7797 & 1.1204 & 0.7019 & 10844 & 0.9693 & & 0.9693 & & \\
\hline & 2 & 0 & 7 & 1.0844 & 1 & 1.2837 & 1 & 1.1761 & 1.7721 \\
\hline & $(0.06)^{*}$ & $(0.06)^{*}$ & $(0.05)^{*}$ & $(0.09)^{*}$ & $(0.07)^{*}$ & $(0.07)^{* *}$ & $(0.07)^{*}$ & $(0.06)^{* *}$ & $(0.25)^{*}$ \\
\hline & $* *$ & $* *$ & $* *$ & $* *$ & $* *$ & $*$ & $* *$ & $*$ & s \\
\hline
\end{tabular}




\begin{tabular}{|c|c|c|c|c|c|c|c|c|c|}
\hline DSIZE & & & & $\begin{array}{r}\mathbf{0 . 0 5 2 0} \\
07 \\
\end{array}$ & & & & & \\
\hline & & & & $\begin{array}{r}(0.08)^{*} \\
* *\end{array}$ & & & & & \\
\hline \multirow{4}{*}{ TANG } & 0.2590 & 0.2062 & 0.2657 & 0.2626 & 0.2761 & $\begin{array}{l}0.19158 \\
\end{array}$ & 0.2761 & 0.22298 & 0.2487 \\
\hline & 7 & 3 & 1 & 21 & 3 & 3 & 3 & 4 & 3 \\
\hline & $(0.02)^{*}$ & $(0.02)^{*}$ & $(0.02)^{*}$ & $(0.02)^{*}$ & $(0.02)^{*}$ & $(0.02)^{* *}$ & $(0.02)^{*}$ & $(0.020)^{*}$ & $(0.01)^{*}$ \\
\hline & $* *$ & $* *$ & $* *$ & $* *$ & ** & * & $* *$ & $* *$ & ** \\
\hline \multirow{2}{*}{ DTANG } & & & & & & 0.25771 & & & \\
\hline & & & & & & 4 & & & \\
\hline
\end{tabular}

\begin{tabular}{lrrrrrrrrr}
\hline GROWT & $\mathbf{- 0 . 0 9 0 2}$ & $\mathbf{- 0 . 1 6 8 0}$ & $\mathbf{- 0 . 1 6 3 0}$ & $\mathbf{0 . 1 9 5 3}$ & $\mathbf{- 0 . 0 6 8 5}$ & $\mathbf{- 0 . 2 8 6 3 6}$ & $\mathbf{- 0 . 0 6 8 5}$ & $\mathbf{- 0 . 1 5 5 0 7}$ & $\mathbf{- 0 . 2 4 4 0}$ \\
H & & & & $\mathbf{8}$ & & & & & \\
\hline & $(0.01)^{*}$ & $(0.01)^{*}$ & $(0.01)^{*}$ & $(0.01)^{*}$ & $(0.01)^{*}$ & $(0.02)^{* *}$ & $(0.01)^{*}$ & $(0.00)^{* *}$ & $(0.01)^{*}$ \\
& $* *$ & $* *$ & $* *$ & $* *$ & $* *$ & $*$ & $* *$ & $*$ & $* *$ \\
& & & & & & & & &
\end{tabular}

\begin{tabular}{lc}
\hline $\begin{array}{l}\text { DGROW } \\
\text { TH }\end{array}$ & $\mathbf{- 0 . 1 8 2 9}$ \\
\hline & $(0.02)^{*}$ \\
$* *$
\end{tabular}

\begin{tabular}{rrrrrrrrrr}
\hline & & & -0001 & - & & & & - \\
& $-\mathbf{0 . 0 0 0 3}$ & $\mathbf{0 . 0 0 0 1}$ & $\mathbf{- 0 . 0 0 0 1}$ & $\mathbf{0 . 0 0 0 1}$ & $\mathbf{- 0 . 0 0 0 3}$ & $\mathbf{- 0 . 0 0 0 3 2}$ & $\mathbf{- 0 . 0 0 0 3}$ & $\mathbf{- 0 . 0 0 0 0 9}$ & $\mathbf{0 . 0 0 0 0}$ \\
& $(0.00)^{*}$ & $(0.00)^{*}$ & $(0.00)^{*}$ & $(0.00)^{*}$ & $(0.00)^{*}$ & $(0.00)^{* *}$ & $(0.00)^{*}$ & $(0.00)^{* *}$ & $(0.00)^{*}$ \\
$* *$ & $* *$ & $* *$ & $* *$ & $* *$ & $*$ & $* *$ & $*$ & $* *$
\end{tabular}

\begin{tabular}{rc}
\hline DRISK & $\mathbf{- 0 . 0 3 0 8 1}$ \\
\hline & $(0.00)^{* *}$
\end{tabular}

\begin{tabular}{|c|c|c|c|c|c|c|c|c|c|}
\hline \multirow[t]{2}{*}{ DPDRB } & & & & & & & & & $\begin{array}{r}1.4042 \\
9\end{array}$ \\
\hline & & & & & & & & & $\begin{array}{r}(0.30)^{*} \\
* *\end{array}$ \\
\hline \multirow{2}{*}{ INFLASI } & & & & & & & & & 0.1486 \\
\hline & & & & & & & & & $(0.06)^{*}$ \\
\hline \multirow[t]{2}{*}{ BUNGA } & & & & & & & & & -1.2954 \\
\hline & & & & & & & & & $\begin{array}{r}(0.20)^{*} \\
* *\end{array}$ \\
\hline \multirow[t]{3}{*}{ Wald chi2 } & $\begin{array}{r}68454 . \\
8\end{array}$ & $\begin{array}{r}61925 . \\
5\end{array}$ & $\begin{array}{r}59891 . \\
9\end{array}$ & $\begin{array}{r}44647 . \\
1\end{array}$ & $\begin{array}{r}38242 . \\
5\end{array}$ & $\begin{array}{r}54237.0 \\
7\end{array}$ & $\begin{array}{r}38242 . \\
5\end{array}$ & 56779.6 & $\begin{array}{r}56876 . \\
8\end{array}$ \\
\hline & $(0.00)^{*}$ & $(0.00)^{*}$ & $(0.00)^{*}$ & $(0.00)^{*}$ & $(0.00)^{*}$ & $(0.00)^{* *}$ & $(0.00)^{*}$ & $(0.00)^{* *}$ & $(0.00)^{*}$ \\
\hline & $* *$ & $* *$ & $* *$ & $* *$ & $* *$ & $*$ & $* *$ & $*$ & $* *$ \\
\hline \multirow[t]{3}{*}{$\mathbf{m}_{1}$} & -1.9872 & -2.1364 & -2.1897 & -2.3077 & -2.2428 & -2.5641 & -2.2428 & -3.1453 & -2.5283 \\
\hline & $(0.05)^{*}$ & $(0.032)$ & $(0.03)^{*}$ & $(0.021)$ & $(0.025)$ & $(0.01)^{* *}$ & $(0.025)$ & & $(0.01)^{*}$ \\
\hline & * & $* *$ & * & $* *$ & $* *$ & $*$ & $* *$ & $(0.01)^{* * *}$ & \\
\hline \multirow[t]{3}{*}{$\mathbf{m}_{2}$} & 0.6357 & 0.6707 & 0.7563 & 0.7423 & 0.7444 & 0.72124 & 0.7444 & 0.20288 & 0.8506 \\
\hline & 9 & 6 & 4 & & 9 & & 9 & & \\
\hline & $(0.524)$ & $(0.502)$ & $\begin{array}{r}(0.4494 \\
)\end{array}$ & $\begin{array}{r}(0.4579 \\
)\end{array}$ & $\begin{array}{r}(0.4566 \\
)\end{array}$ & $(0.4708)$ & $(0.83)$ & $(0.83)$ & $(0.39)$ \\
\hline
\end{tabular}




\begin{tabular}{|c|c|c|c|c|c|c|c|c|c|}
\hline Sargan & $\begin{array}{r}55.292 \\
6\end{array}$ & $\begin{array}{r}41.785 \\
1\end{array}$ & $\begin{array}{r}49.316 \\
7\end{array}$ & $\begin{array}{r}56.851 \\
7\end{array}$ & $\begin{array}{r}62.163 \\
5\end{array}$ & 58.0094 & $\begin{array}{r}62.163 \\
5\end{array}$ & 57.4356 & $\begin{array}{r}58.290 \\
1\end{array}$ \\
\hline & $(0.5766$ & $(0.6089$ & $(0.3047$ & $(0.2992$ & $(0.1580$ & & & & $(0.5016$ \\
\hline & ) & ) & ) & ) & ) & & (0.158) & & ) \\
\hline \multirow{4}{*}{$\begin{array}{l}\text { Lag LEV } \\
\text { FE }\end{array}$} & 0.4243 & 0.3496 & 0.4207 & 0.4234 & 0.4220 & \multirow{2}{*}{0.42759} & 0.4220 & \multirow{2}{*}{0.42433} & 0.4174 \\
\hline & 8 & 9 & 5 & 4 & 3 & & 3 & & 3 \\
\hline & $(0.0)^{* *}$ & $(0.0) * *$ & $(0.1)^{* *}$ & $(0.03)^{*}$ & $(0.03)^{*}$ & $(0.03)^{* *}$ & $(0.03)^{*}$ & $(0.03)^{* *}$ & $(0.03)^{*}$ \\
\hline & $*$ & $*$ & $*$ & $* *$ & $* *$ & $*$ & $* *$ & $*$ & $* *$ \\
\hline \multirow{4}{*}{$\begin{array}{l}\text { Lag LEV } \\
\text { OLS }\end{array}$} & 0.8937 & 0.9084 & 0.8941 & 0.8923 & 0.8944 & \multirow{2}{*}{0.88798} & 0.8944 & \multirow{2}{*}{0.89243} & 0.8933 \\
\hline & 7 & 8 & 7 & 3 & 4 & & 4 & & 2 \\
\hline & $(0.0) * *$ & $(0.0) * *$ & $(0.0)^{* *}$ & $(0.02)^{*}$ & $(0.02)^{*}$ & $(0.02)^{* *}$ & $(0.02)^{*}$ & $(0.02)^{* *}$ & $(0.02)^{*}$ \\
\hline & $*$ & $*$ & $*$ & $* *$ & $* *$ & $*$ & $* *$ & $*$ & $* *$ \\
\hline
\end{tabular}

Sumber : Data hasil olahan

Keterangan : Variabel DPROF adalah variable PROF, jika nilainya lebih besar dari median variable PROF, akan diberi nilai 0 , selain itu, bernilai sama dengan variable PROF.

Variabel DSIZE adalah variable SIZE, jika nilainya lebih kecil dari median variable SIZE, akan diberi nol, selain itu, nilainya sama dengan variable SIZE.

Variabel DGROWTH adalah variable GROWTH, jika nilainya lebih besar dari median variable GROWTH, akan diberi nol, selain itu, nilainya sama dengan variable GROWTH.

Variabel DTANG adalah variable TANG, jika nilainya lebih kecil dari median variable TANG, akan diberi nol, selain itu, nilainya sama dengan variable TANG.

Variabel DRISK adalah variable RISK, jika nilainya lebih besar dari median variable RISK, akan diberi nol, selain itu, nilainya sama dengan variable RISK.

$* * *$ signifikan pada level $\mathrm{p}<0.01, * *$ signifikan pada level $\mathrm{p}<0.05$ dan $*$ signifikan pada level $\mathrm{p}<0.1$.

Angka dalam kurung menyatakan standard Error, kecuali statistic Wald, $\mathrm{m}_{1}, \mathrm{~m}_{2}$ dan Sargan menyatakan probability value

Kolom yang diberi nomor 1 sampai dengan 9 menunjukkan model yang dipergunakan dalam penelitian ini. Dari table terlihat bahwa seluruhnya uji Wald signifikan pada level 1\%, menunjukkan bahwa model ini terdapat hubungan antara variable variable bebas dengan variable tak bebas.

Uji Sargan memberi hasil bahwa tidak signifikan, artinya penggunaan variable instrumen yang jumlahnya melebihi jumlah parameter yang diduga, terbukti valid. Sedangkan uji Arelleano dan Bond, untuk $\mathrm{m}_{1}$ signifikan pada level $5 \%$ dan $1 \%$, sehingga terbukti terdapat autokorelasi pada error first difference orde ke-1, sedangkan uji $\mathrm{m}_{2}$ tidak signifikan, sehingga tidak terdapat autokorelasi pada error first difference pada error first difference orde orde ke-2. Uji ketidak biasan dilakukan dengan cara membandingkan koefisien variable dependent (dalam hal ini lag Leverage) yang diperoleh dari proses GMM terletak diantara lag leverage FE dan lag leverage PLS/OLS, hasilnya menunjukkan bahwa koefisien variabel lag Leverage dari proses GMM terletak diantara diantara koefisien lag leverage FE dan koefisien lag leverage PLS/OLS, jika model dijalankan dengan FE dan OLS. Penelitian Maghyereh (2005) menunjukkan bahwa koefisien lag variable Leverage dengan pendugaan OLS akan bias keatas (upward bias) dan FE bias kebawah (downward bias).

Hasil analisis pada kolom 1 sampai dengan kolom 9 menunjukkan bahwa koefisien Lag leverage (Lag LEV) nilainya positif, signifikan dan lebih kecil dari 1. Penelitian ini mampu membuktikan bahwa sector 2 di Indonesia secara rata-rata menerapkan model model dinamis. Hasil ini sesuai dengan dari penelitian Ozkan (2001), Gaud et. al. (2005), Xu (2005), Maghyereh (2005), Haron dan Ibrahim (2012), Haron et al. (2013), Haron et al. (2013) dan Yang, Albaity dan Hassan (2015), Yang, Albaity dan Hassan (2015), Kinyua dan Muria (2017), Syihab (2018)). Dengan demikian, secara rata-rata perusahaan di Indonesia masih dapat meningkatkan leveragenya sampai batas leverage yang ditargetkan/leverage optimal.

Kolom 1 sampai dengan kolom 9 menunjukkan bahwa koefisien variabel profitability (PROF) negatif dan signifikan. Bontempi (2002) menyatakan bahwa variable profitability merupakan variable yang dapat dipergunakan untuk memprediksi apakah suatu perusahaan menerapkan Trade Off Theory atau Pecking Order Theory. Hasil yang negative menunjukkan bahwa perusahaan- perusahaan yang listing di BEI ketika ekonomi makro membaik, sehingga profit yang diperoleh meningkat, sehingga ketersediaan 
dana internal meningkat maka sesuai dengan Pecking Order Theory cenderung untuk mengurangi hutangnya. Profitability merupakan proxy untuk ketersediaan dana internal, meningkatnya profitability menyebabkan meningkatkan free cash flow. Hasil ini sama dengan penelitian (Titman danWessels, (1988); Rajan dan Zingales, (1995); Heshmati (2001), Ozkan (2001); Lööf (2003); Nivorozhkin (2003); Haas and Peeters (2004), Gaud et. al. (2005), Drobetz and Wanzenried (2004), Xu (2007), Haron and Ibrahim (2012), Mahakud and Mukerjee (2011), Maghyereh (2005) dan Effendi, Heriyandi dan Rum (2016).

Pada model pada kolom kedua, penulis menambahkan Lag Profitability, tujuan dari penambahan variable lag profitability tersebut untuk menguji konsistensi dari Pecking Order Theory. Hasil pada kolom (2) koefisien Lag PROF positif dan signifikan, sesuai dengan Ozkan (2001) dan Gaud et. al (2005). Hal tersebut berarti perilaku Pecking Order Theory hanya berlaku pada jangka pendek (short run), sedangkan jangka panjang akan memperhatikan profitability waktu sebelumnya. Hasil ini sesuai dengan Dynamic Trade-Off Theory, yaitu bank mempertimbangkan profitability waktu sebelumnya dalam memberikan kredit terhadap perusahaan (Gaud, et al. 2005). Jensen (1986) dalam Ozkan (2001) menyatakan bahwa keuntungan yang tinggi pada masa lalu, akan meningkatkan kepercayaan buat supplier. Sedangkan Nunkoo dan Boateng (2010) menyatakan bahwa keuntungan yang tinggi pada masa lalu, akan meningkatkan taxes shield, sehingga perusahaan dapat meningkatkan hutang mereka.

Penulis menambahkan variable DPROF, dimana variable ini akan bernilai 0 , jika variable Profitability lebih besar dari median variable Profitability dan selain itu akan sama dengan variable Profitability. Hasil analisis dapat dilihat pada kolom 3, menunjukkan bernilai negatif dan signifikan. Artinya perusahaan yang memiliki profitabilitas rendah, cenderung akan lebih sensitive terhadap leverage.

Kolom 1 sampai dengan kolom 9 menunjukkan bahwa koefisien variabel SIZE positif dan signifikan. Sesuai dengan Trade off Theory, perusahaan besar cenderung lebih terdiversifikasi produknya sehingga kreditur cenderung menganggap lebih aman selain itu volatilitas pendapatan cenderung rendah sehingga dianggap lebih mampu menjamin kepastian pembayaran pokok dan bunga hutang (Graham et al., 1998; Gaud et al. 2005).

Kemudian penulis menambahkan variabel DSIZE, yang akan bernilai 0 jika lebih kecil dari median variabel SIZE, selain itu, akan sama dengan variable SIZE. Hasil pada kolom 4 positif dan signifikan, artinya perusahaan yang memiliki SIZE besar, cenderung lebih leverage dibandingkan dengan perusahaan kecil. Temuan ini menunjukkan bahwa terdapat size effect. Penelitian Marsh (1982) menunjukkan bahwa perusahaan besar memiliki kemampuan lebih baik dalam mengakses pasar modal, sehingga akan meningkatkan leveragenya. Lebih lanjut Leary et al. (2009) dalam Ramakrishnan (2012) meyatakan bahwa variable SIZE dalam dijadikan sebagai proxy kemampuan perusahaan dalam mengakses pasar modal.

Kolom 1 sampai dengan kolom 9 menunjukkan bahwa koefisien variabel Tangibility (TANG) positif dan signifikan. Perusahan yang memiliki Fixed Asset yang tinggi akan dapat meminjam dengan tingkat bunga yang rendah karena fixed asset tersebut dapat dipakai sebagai jaminan sehingga memberikan rasa keamanan bagi kreditor dan mengurangi biaya keagenan hutang (Jensen \& Meckling, 1976). Fama dan French (2002) dan Frank and Goyal (2008) sebagai variabel penentu struktur modal perusahaan. Hasil penelitian sejalan dengan penelitian Heshmati (2001), Drobetz and Wanzenried (2004), Gaud et. al. (2005), Maghyereh (2005), Xu (2007), Haron and Ibrahim (2012), Nosita, (2016), Effendi, Heriyaldi dan Rum (2016).

Kemudian penulis menambahkan variabel DTANG, yang akan bernilai 0 jika lebih besar dari median variabel Tangibility, selain itu akan bernlai sama dengan variable tangibility. Hasil pada kolom 6 positif dan signifikan, artinya perusahaan yang memiliki Tangibility besar, cenderung akan mampu meningkatkan leverage karena memiliki fixed asset yang lebih besar dan dikenakan bunga pinjaman yang lebih rendah oleh kreditor.

Kolom 1 sampai dengan kolom 9 menunjukkan bahwa koefisien variabel Growth Opportunity (GROWTH) negatif dan signifikan. Perusahaan yang memiliki kesempatan untuk tumbuh yang tinggi, menunjukkan bahwa untuk menunjang pertumbuhan yang tinggi itu, dibutuhkan banyak modal. Kondisi seperti ini menyebabkan aliran kas perusahaan kurang stabil, sehingga kemampuan untuk membayar kewajiban secara rutin menjadi kurang. Ozkan (2001) menemukan bahwa jumlah hutang yang dikeluarkan oleh perusahaan berbanding terbalik dengan pertumbuhan perusahaan.

Purwanto Widodo, et.al (Determinan Leverage Optimal Di Bursa Efek Indonesia...) 
Sebagaimana Gaud et. al. (2005), penulis menambahkan variabel dummy DGROWH yang akan bernilai 0 jika lebih kecil dari median variable GROWH dan selain itu, akan bernilai sama dengan variabel GROWH dengan variabel dummy GROWTH yang bernilai 1 . Hasilnya sesuai dengan hasil Gaud et. al. (2005) bernilai negative dan signifikan. Hasil negative ini menunjukkan bahwa perusahaan yang memiliki Growth Opportunity kecil akan cenderung lebih banyak menggunakan hutang (more leverage).

Kolom 1 sampai dengan kolom 9 menunjukkan bahwa koefisien variabel Business Risk (RISK) negatif dan signifikan. Perusahaan yang memiliki Business Risk tinggi, memiliki volatilitas pendapatan yang tinggi, sehingga memiliki risiko kebangkrutan yang tinggi karena tingginya ketidakpastian dalam pembayaran pokok dan bunga hutang. Hasil ini sesuai dengan penelitian Heshmati, (2001); Lóóf, (2003); Nivorozhkin, (2003) dan Maghyereh (2005).

Kemudian penulis menambahkan variabel DRISK, yang akan bernilai 0 jika lebih kecil dari median variabel RISK, selain itu akan bernilai sama dengan variable RISK. Hasil pada kolom 8 negatif dan signifikan, artinya perusahaan yang memiliki risiko kecil, cenderung akan lebih leverage.

Kolom 9 menunjukkan bahwa variable pertumbuhan ekonomi (GPDRB) berhubungan positif dengan signifikan. Hal ini sesuai dengan penelitian Haron dan Ibrahim (2012) pada kelompok saham Syariah di Malaysia, khususnya untuk leverage yang diproxykan dengan Total hutang dengan Total Asset. Hasil serupa Haron et al. (2013) pada pasar modal Thailand, Haron et al. (2013) pada pasar Malaysia.

Kolom 5 menunjukkan bahwa variable inflasi (INFLASI) berhubungan positif dan signifikan. Inflasi yang tinggi menyebabkan harga saham menjadi undervalued, sehingga manajer cenderung untuk mengurangi pendanaan menggunakan saham dan meningkatkan hutang. Hasil ini sesuai dengan penelitian Frank dan Goyal (2009), Haron et al. (2012), Haron et al. (2013), Haron (2014), Ying et al. (2016), Ying et al. (2015).

Kolom 5 menunjukkan bahwa variable suku bunga (BUNGA) berhubungan negative dan signifikan, semakin tinggi suku bunga akan menyebabkan hutang menjadi mahal, sehingga terdapat kecenderungan perusahaan untuk mengurangi hutang. Hasil ini sejalan dengan penelitian Antoniou et al. (2008).

Kecepatan penyesuaian antara $34.18 \%$ sampai $41.37 \%$, mendekati Nosita pada sector non keuangan (2016) 40.7\%; Syahara dan Sukarno (2015) yang meneliti perusahaan yang termasuk LQ-45 dan non keuangan periode 2005 - 2014, 38.15\%; Effendi et al. (2016) pada sector manufaktur yaitu antara 22\% 47\%, Yang et al. (2015) pada industry mamufaktur 38.6\%. Ghouzani (2013) di Tunisia 16.4\% dan 18.3\%, Getzmann, Lang and Spermann (2010) di Asia antara 27\% - 39\%, Serrasqueiro and Nunes (2005) di Portugal 33\% dan 34\%, Reihard dan Li (2010) 36\% - 46\%, Nugroho et al. (2015) pada industry perkebunan $25.40 \%$. Besarnya kecepatan penyesuaian penelitian ini antara $30 \%$ sampai $40 \%$ tersebut menunjukkan bahwa sesuai dengan Dynamic Trade Off Theory.

Penelitian ini menunjukkan bahwa untuk menuju leverage optimal, perusahaan yang termasuk sector 2 akan membutuhkan waktu antara 1.30 - 1.86 tahun, sedangkan jika terjadi guncangan pada error term sebesar 1 unit, maka akan kembali ke kondisi semula, membutuhkan waktu selama 1.42 sampai 1.86 tahun.

\section{KESIMPULAN}

Penelitian ini mampu membuktikan bahwa struktur modal perusahaan yang listing di Bursa Efek Indonesia khususnya sector 2, secara rata-rata mengikuti Dynamic Trade Off Theory, sehingga untuk meningkat value of the firm, dapat dilakukan dengan menambah tingkat hutang perusahaan sampai dengan batas yang ditentukan oleh Peraturan Menteri Keuangan (PMK) nomor 169/PMP.010/2015.

Variabel karakteristik perusahaan dan ekonomi makro merupakan variabel yang patut dipertimbangkan dalam menduga leverage optimal. Temuan dari penelitian ini adalah perusahaan dalam pengelolaan profitability, dalam jangka pendek menggunakan Pecking Order Theory dan jangka panjang Dynamic Trade Off Theory. Perusahaan yang memiliki profitability tinggi cenderung akan mengurangi tingkat hutangnya. Selain itu, terlihat adanya pengaruh SIZE (size effect), dimana perusahaan yang size besar, secara rata-rata akan menggunakan leverage yang tinggi. Perusahaan yang memiliki asset nyata (tangibility) besar akan menggunakan hutang yang lebih besar. Sedangkan perusahaan yang memiliki Growth Opportunity dan Risiko Bisnis kecil, akan cenderung memerlukan hutang yang lebih banyak. 


\section{DAFTAR PUSTAKA}

Alnori, Faisal and Faisal Alqahtani. 2019. Capital structure and speed of adjustment in non-financial firms: Does sharia compliance matter? Evidence from Saudi Arabia. Emerging Markets Review 39 (2019) $50-67$

Arellano, Manual and Stephen Bond. 1991. Some Tests of Specification for Panel Data: Monte Carlo Evidence and an Application to Employment Equations. The Review of Economic Studies, Vol. 58, No. 2 (Apr., 1991), pp. 277-297.

Banerjee. S., Heshmati, A. and Wihlborg, C. 2004. The Dynamics Of Capital Structure. Research in Banking and Finance, Vol.4, pp. 275-297

Blundell, R and Bond, S 1998, Initial conditions and moment restrictions in dynamic panel data models, Journal of Econometrics, vol. 87, no. 1, pp. 115-43

Clark, B., Francis, B. \& Hasan, I. 2009. Do firms adjust toward target capital structure? Some international evidenceAvailable at http://ssrn.com/abstract=1364095

Cook, Douglas O and Tian Tang. 2006. Macroeconomic Conditions and Capital Adjustment, Culverhouse College of Business, University of Alabama. Electronic copy available at: http://ssrn.com/abstract=1101664

Dincergok, B., dan Yalciner, K. 2011. Capital structure decisions of manufacturing firms' in developing countries. Middle Eastern finance and economics, 12, April 2011.

Drobetz, Wolfgang and Gabrielle Wanzenried.2006. What Determines The Speed of Adjustment to The Target Capital Structure. Aplied Financial Economics. Vol. 6, pp. 941-958

Drrsomsak, R, Paudyal, K and Pescetto, G. 2009. Debt maturity and the 1997 Asian financial crisis. Journal of Multinational Financial Management, vol 19, no. 1, pp. 26-42

Effendi, N; Heryaldi dan I A Rum. Jurnal. 2016. Faktor Determinan Struktur Modal \& Kecepatan Penyesuaian Target pada Industri Manufaktur. seminar "Research Seminar Series in Economics (RSSE)", 24 Maret 2016, Pusat Studi Ekonomi dan Pembangunan, Fakultas Ekonomi \& Bisnis, Universitas Padjadjaran Bandung, Indonesia.

Fischer, E., Heinkel, R. and Zechner, J. 1989. Dynamic Capital Structure Choice: Theory and tests. Journal of Finance, 44, 19-40

Flannery, M. J. and K. P. Rangan. 2006. Partial Adjustment toward Target Capital Structures, Journal of Financial Economics Vol 79, pp.469-6

Flannery, Mark, \& Kristine W. Hankins. 2007. Estimating Dynamic Panels, Working Paper

Frank, M.Z., and Goyal, V.K. 2009. Capital structure decisions: Which factors are reliably important? Financial Management, 38(1), 1-37.

Gaud, P., Jani, E., Hoesli, M. and Bender, A. 2005. The Capital Structure of Swiss Companies: An Empirical Analysis Using Dynamic Panel Data. European. Financial Management. 11, 51-63.

Getzmann, Andre, Sebastian Lang and Klaus Spremann. 2010. Determinan of the target Capital Structure and Adjustment Speed Evidence from Asia Capital Market. Swiss Institute of Banking and Finance

Green, William H. 2003. Econometric Analysis. Prentice-Hall

Haas De, Ralph and Marga Peeters. 2006. The Dynamic Adjustment Towards Target Capital Structures Of Firms In Transition Economies. Economic of Transition Volume 14(1), 133-169

Hackbarth,D., J. Miao and E. Morellec. 2006, Capital Structure, Credit Risk, And Macroeconomic Conditions, Journal of Financial Economics 82 (2006).

Haron, Razali dan Khairunisah Ibrahim. 2012. Target Capital Structure And Speed Of Adjustment: Panel Data Evidence On Malaysia Shariah Compliant Securities. International Journal of Economics, Management and Accounting 20, no.2 (2012). The International Islamic University Malaysia.

Haron, Razali, Khairunisah Ibrahim, Fauzias Mat Nor dan Izani Ibrahim. 2013. Dynamic Adjustment towards Target Capital Structure: Thailand Evidence. Jurnal Pengurusan 39(2013) 73 - 82

Haron, Razali; Khairunisah Ibrahim, Fauzias Mat Nor dan Izani Ibrahim. 2013. Factors Affecting Speed of Adjustment to Target Leverage: Malaysia Evidence. Global Business Review 14(2) 243-262 @ 2013 IMI SAGE Publications

Heshmati, A. 2001. The Dynamics of Capital Structure: Evidence From Swedish Micro and Small Firms, Research in Banking and Finance. Volume 2,199-241

Huang, R and Ritter, JR 2009, 'Testing theories of capital structure and estimating the speed of adjustment', Journal of Financial and Quantitative Analysis, vol. 44, no. 2, pp. 237-71 
Iliev, Peter and Ivo Welch. 2010. Reconciling Estimates of the Speed of Adjustment of Leverage Ratios. Electronic copy available at: http://ssrn.com/abstract $=1542691$

Jensen, M.C and W.H. Meckling. 1976. Theory of the Firm: Managerial Behavior, Agency Costs and Ownership Structure. Journal of Financial Economics, Vol. 3, No. 4, pp. 305-360

Kinyua, John Brian dan peter W Muriu. 2017. Determinants of Capital Structure of Agricultural Firms in Kenya. European Scientific Journal March 2017 edition Vol.13, No.7 ISSN: 1857 - 7881.

Kraus, A and Litzenberger, RH 1973, A state-preference model of optimal financial leverage', Journal of Finance, vol. 28, no. 4, pp. 911-22.

Lemmon, Micheal L, Michael R. Roberts and Jaime F. Zender. 2008. Back to the Beginning: Persistence and the Cross-Section of Corporate Capital Structure. The Journal of Finance, Vol. 63, No. 4 (Aug., 2008), pp. $1575-1608$

Lóóf, H. 2003. Dynamic Optimal Capital Structure and Technological Change. Working Paper, Institute for Studies in Education and Research, Stockholm

Mahakud, Jitendra and Sulagna Mukherjee. 2011. Determinants of Adjustment Speed to Target Capital Structure: Evidence from Indian Manufacturing Firms. International Conference on Economics and Finance Research IPEDR vol.4. IACSIT Press, Singapore

Marsh, P 1982, The choice between equity and debt: An empirical study, Journal of Finance, vol. 37, no. 1, pp. 121-44.

Mat Nor, F, Haron, R, Ibrahim, I Alias, N and Ibrahim, K 2011, 'Determinants of target capital structure: Evidence on South East Asia countries', Journal of Business and Policy Research, vol. 6, no. 3, pp. 3961

Mazur, Kinga. 2007.The Determinants of Capital Structure Choice: Evidence from Polish Companies. International Atlantic Economic Society 13, 495-514

Modigliani, F and Miller, M., 1963, Corporate Income Taxes and The Cost of Capital: A Correction, American Economic Review, 53, June, pp. 433-443

Modigliani, F., and M. Miller, 1958, The Cost of Capital, Corporation Finance, and the Theory of Investment, American Economic Review 48 (3), pp. 261-297

Myers, SC 1977, 'Determinants of corporate borrowing', Journal of Financial Economics, vol. 5, no. 2, pp. 14775.

Myers, SC and Majluf, NS 1984, Corporate financing and investment decisions when firms have information that investors do not have', Journal of Financial Economics, vol. 13, no. 2, pp. 187-221

Nivorozhkin, Eugene. 2003.The Dynamic of Capital Structure in Transition Economies. Discussion Papers, Bank of Finland Intitute for Economies inTransition, BOFIT, No.2, 1-31

Nosita, Farida. 2016. Struktur Modal Optimal Dan Kecepatan Penyesuaian: Studi Empiris Di Bursa Efek Indonesia. Ekuitas: Jurnal Ekonomi dan Keuangan. Volume 20, Nomor 3, September 2016 : 305 - 324

Nugroho, Sigit Dani; Hermanto Siregar, Adler Haymans Manurung dan Nunung Nuryartono. 2015. Speed Of Adjustment Towards The Leverage Target Plantation Companies In Indonesia. International Journal of Business and Management Review Vol.3, No.10, pp.72-82, November 2015.

Nunkoo, PK and Boateng, A 2010, 'The empirical determinants of target capital structure and adjustment to long-run target: Evidence from Canadian firms', Applied Economics Letters, vol. 17, no. 10, pp. 98390.

Ozkan, A 2001, Determinants of capital structure and adjustment to long run target: Evidence from UK company panel data, Journal of Business Finance and Accounting, vol. 28, no. 1-2, pp. 175-98

Rajan, RG and Zingales, L 1995, What do we know about capital structure? Some evidence from international data, Journal of Finance, vol. 50, no. 5, pp. 1421-60

Reinhard, Ludwig dan Steven Li. 2010. A note on capital structure target adjustment - Indonesian evidence. International Journal of Managerial Finance Vol. 6 No. 3, 2010 pp. 245-259.

Ross, S A, R W. Westerfield and B D. Jordan. 2008. Corporate Finance Fundamentals ed. 8. Mc. Graw Hill

Ross, Stephen A. 1977. The Determination of Financial Structure: The Incentive-Signalling Approach. The Bell Journal of Economics, Vol. 8, No. 1 (Spring, 1977), pp. 23-40

Saadah, S and R Prijadi. 2012. Capital Structure's Dynamic Response to Exogenous Variables: A Case of Listed Manufacturing Firms in Indonesia. International Journal of Financial Research. Vol. 3, No. 2; April 2012 
Syihab, Faizah. 2018. How fast do Indonesian firms in achieving targeted capital structure?. Al Tijarah: Vol. 4 No. 2, Desember 2018 (1-13). p-ISSN: 2460-4089 e-ISSN: 2528-2948. Available at: http://ejournal.unida.gontor.ac.id/index.php/altijarah

Taggart Jr, RA, 1986, Corporate Financing: Too Much Debt?, Financial Analysts Journal, vol. 42, no. 3, pp. $35-42$

Titman, Sheridan and Roberto Wessels. 1988. The Determinants Of Capital Structure Choice. Journal of Finance 43, 1-19.

Verbeek, Marno. 2004. 2nd edition. A Guide to Modern Econometrics. John Wiley \& Sons Ltd

Widarjono, Agus. 2009. Ekonometrika:teori dan aplikasi untuk ekonomi dan bisnis. Yogyakarta Ekonisia Fakultas Ekonomi.

Xu, Zhaoxia. 2007. Do Firms Adjust Toward a Target Leverage Level? Working Paper/Document de travail 2007-50. Bank of Canada

Yang, Ying; Mohamed Albaity dan Che Hashim Bin Hassan. 2015. How Dynamic Capital Structure Works in China?. International Journal of Research in Business and Technology. Volume 7, No. 2. November 2015.

Ying, Yang; Mohamed Albaity and Fauzi Zainir. 2016. Determinants of Capital Structure: A Comparison between Industrial and Consumer Sectors in China. Asian Journal of Business and Accounting 9(2). 